\title{
An Assessment of Students' Satisfaction Level from Learning Management Systems: Case Study of Payamnoor and Farhangian Universities
}

\author{
Parisa Shayan \\ Department of Computer and Instructional Technology \\ Teacher Education, Eastern Mediterranean University (EMU), \\ Famagusta, Cyprus
}

\begin{abstract}
Learning Management Systems (LMS) have played a significant role in education. The purpose of this study is to investigate the acceptance level of LMS amongst students of two Universities in Tehran, Payamnoor and Farhangian. The total number of participants was 200. This study was directed based on a quantitative research method and data collection from a questionnaire which was then interpreted according to accurate statistical procedures through SPSS software. Results show that most students, regardless their gender, age, and department were satisfied with the usage of Payamnoor and Farhangian LMSs. However, a student's grades seem to play a significant role regarding his or hers level of satisfaction from the LMS.
\end{abstract}

Keywords-E-learning; LMS; TAM; learners

\section{INTRODUCTION}

Learning Management System (LMS) is an application software that has played a significant role in education. Such a software can be designed to augment and facilitate instructional activities including registration and management of education courses, analyzing skill gaps and reporting and delivery of electronic courses simultaneously [1]. In the private section, an LMS can also be helpful to maintain and develop the business by training employees. Since an education system needs to have mechanisms of access control, communication and results monitoring, an LMS can be considered as a solution. An LMS operates as an infrastructure in order to administer and distribute the instructional content, classify and evaluate learning objectives, follow the development of training goals, and collect data for managing the education process [2]. It is a platform with diverse resources and various educational activities that is embedded within courses. It provides opportunities to monitor each learner's activities with different types of tests, assignments, and documents. Moreover, it provides easy communication and collaboration between instructors and students via discussion forums [3]. LMS allows instructors to create online courses, and training courses. Along with creating, managing and delivering e-courses to their learners, instructors can also track their learners' progress by accessing detailed reports and statistics. Another important aspect of an LMS is that it provides learners with online classrooms where they can interact and learn in an interactive environment. To create such an environment, LMS allows

\author{
Ersun Iscioglu \\ Department of Computer and Instructional Technology \\ Teacher Education, Eastern Mediterranean University (EMU) \\ Famagusta, Cyprus
}

instructors to upload all their courses and training materials such as videos, presentations, PDFs or even live web content such as wikis and blogs to a central location, i.e. the online classroom [4]. An LMS has also some features to help instructors to manage their students better. For instance, they can organize students into groups or classes to centralize reporting and assignment or quizzes. With advanced reports and statistics, tracking the progress of large groups or individual learners would be easy. Moreover, instructors save valuable time in grading tests, and assessing the results. As the LMS automates the grading of hundreds of test papers and students can instantly see the results [5]. Clarity may be an added benefit that can be achieved through its capability of accepting proposals from the users regarding additional characteristics [6]. Most experts believe that an LMS should be more based on peer interaction so that learners can improve their skills by learning from each other and taking advantages of other students' knowledge [7].

In considering the above, in Iran universities, students can easily interact with professors and curriculum planners through discussion forums in the LMSs. For examples, Payamnoor and Farhangian LMSs, two of the most powerful LMSs in Iran, facilitate the exchange of information and communication between the students and instructors at anytime. Although both have been successful in e-learning, there are still some technical issues in using them. It is in light of this fact that the different viewpoints of Iranian students about Payamnoor and Farhangian LMSs are investigated [8]. The present study aims to provide an in-depth understanding of the current position of LMSs in Iranian universities by examining the level of students' satisfaction from LMSs in Farhangian and Payamnoor Universities.

\section{THEORETICAL BACKGROUND}

An LMS is a term utilized to describe a web-based technology in order to design, implement and evaluate a particular learning process. An LMS is usually used as a platform and interface to set e-learning materials to the net. Generally, an LMS enables instructors to create and deliver instructional content, monitor students' activities, and evaluate students' performance [9] or, as elsewhere described, a software that automates the administration of training events 
[10]. All LMSs manage registered users log-ins, manage course catalogs, record data from learners and provide reports to the management. LMSs have been extensively used particularly in the realm of modern education. Regardless of the education approach, distant or traditional, LMSs have contributed considerably to the progress of higher education in colleges and universities. With the advent of LMSs as well as the increasing growth of using computers in both personal and professional areas, numerous students and instructors have been attracted to e-learning [11]. LMSs have greatly focused on students' learning needs and instructors' requests related to instructional tasks [12]. The concept of Technology Acceptance Model (TAM) was introduced in [13] in order to examine students' acceptance of LMSs in the university. This model is designed and built upon the Theory of Reasoned Action (TRA) which is considered as a foundation for both the Technology Acceptance Model (TAM) and the Theory of Planned Behavior (TPB). TPB explains the influence of a belief on attitudes towards forming, directing and dictating of behaviors [14].

Generally, TAM consists of five main components: PU, PEU, ATUT, BIT, and ATU [15-17]. According to [13], Perceived Ease of Use (PEU), Perceived Usefulness (PU), and Attitude Towards Using Technology (ATUT) have a considerable impact on Actual Technology Use (ATU). Behavioral Intention to Use Technology (BIT) and Actual Technology Use (ATU) are additional parameters.

\section{RESEARCH BACKGROUND}

Nowadays, most universities have invested in LMS to deliver course materials and content to students. An increase in student satisfaction and a decrease in costs and in dropout rates has been reported [18-20]. It has been reported that there is no significant relationship between students' satisfaction level of using LMS and their gender [21, 22] and age [23, 24]. However, some other researchers believe that older respondents are more satisfied with LMS [21]. On the other hand, most researches show that students' grades play a major role on their satisfaction level $[24,25]$. The department has no remarkable impact on students' gratification level $[25,26]$. Some studies show that there is no considerable relationship between gender [27, 28] or age [23, 24] and students' perceived usefulness. However, the latter is disputable [29]. The students' grades have a significant effect on perceived usefulness [24, 25], but not the department $[25,30]$. There is no substantial difference between male and female students' perceived ease of use [27, 28]. However, age has a significant impact [29, 31] and there is a remarkable effect of students' grades [24, 25]. The department has no noteworthy impact $[25,30]$. There is no considerable relationship between the students' gender [27, $28]$, age $[23,24,30]$, grades $[32,33]$ and department $[25,30]$ and the students' behavioral intention to use the LMS]. Further, that there is no considerable relationship between gender [21, $22]$, age $[23,24,30]$ or department $[25,26]$ and the students' attitude toward using the LMS. Whereas, there is a significant impact of between students' grades [24, 25]. no considerable relationship between gender [21, 22], age [22-24] or their department $[25,30]$ and the students' actual technology use. However, there is a significant effect of students' grades [24, 34

\section{RESEARCH QUESTIONS}

1) What is the LMS satisfaction level of the students according to the current LMS model?

2) Is there any relationship between LMS level satisfaction of students and gender?

3) Is there any relationship between LMS level satisfaction of students and age?

4) Is there any relationship between LMS level satisfaction of students and grade?

5) Is there any relationship between LMS level satisfaction of students and department?

6) What is the LMS satisfaction level of the students according to perceived usefulness?

7) What is the LMS satisfaction level of the students according to perceived ease of use?

8) What is the LMS satisfaction level of the students according to behavioral intention to use technology?

9) What is the LMS satisfaction level of the students according to attitude toward using technology?

10) What is the LMS satisfaction level of the students according to actual technology use?

\section{RESEARCH METHOD}

\section{A. Population and Sampling}

The population of this study were Iranian students from two universities in Tehran (Farhangian and Payamnoor) in the academic year of 2015-2016, fall semester. The total population was over 700 people and the total number of candidates was 200 Iranian students who already had the experience of working with an LMS. 29.5\% (59) of the candidates were female and $70.5 \%$ (141) of them were male. $91 \%$ (182) of them were in the age range of 20 to $30,3.5 \%$ (7) of them were in between 31 to 40, and $5.5 \%$ (11) of them were over 40 years old. As it can be seen, $4.5 \%$ (9) of the candidates were freshman, both 2 nd and 3rd grade students comprise the same portion of the sample, by $31.5 \%$ (63) participants, while $19.5 \%$ (39) of the candidates were senior and the population of the graduate students was $13 \%$ (26).

\section{B. Research Questionnaire}

In order to collect quantitative data, a close-ended questionnaire was used. In this study, the applied questionnaire was divided into two parts: The first one contained demographic information (gender, age, grade, and department) and the second part was extracted from [17]. It consisted of 30 items using a five point Likert scale. The Likert scale items comprised strongly disagree (1), disagree (2), agree (3), strongly agree (4) and neutral (5). As shown in Table I, for each construct Cronbach Alpha was $>0.7$ and Cronbach Alpha for our sample was 0.846 as well. Similarly, the total amount of Cronbach Alpha was 0.923, which means that the questionnaire is acceptable in terms of reliability. Consequently, all constructs are considered reliable [17]. 
TABLE I. STATISTICS RESULT OVERVIEW

\begin{tabular}{|c|c|c|c|c|}
\hline & AVE & Composite Reliability & R Square & $\boldsymbol{\alpha}$ \\
\hline ATU & 0.585232 & 0.908027 & 0.418542 & 0.882350 \\
\hline ATUT & 0.608817 & 0.903059 & 0.612458 & 0.871126 \\
\hline BIT & 0.595598 & 0.854259 & 0.424390 & 0.771428 \\
\hline PEU & 0.624012 & 0.892189 & & 0.848471 \\
\hline PU & 0.608465 & 0.902827 & & 0.870218 \\
\hline
\end{tabular}

\section{Data Analysis}

Quantitative data gathered from the questionnaire was analyzed through SPSS, Version 22.0. Autonomous sample ttests were also conducted to determine the differences between genders [35]. In order to test the relationship between each variable in contrast to the student's status, ANOVA and LSD were employed.

\section{RESUlts}

\section{1) Question1:}

As Table II illustrates, the minimum score is 30 , while the maximum score is 120 . As shown, the satisfaction level of the students is $63.53(52.93 \%)$. The result is consistent with [1820].

TABLE II. STUDENTS' SATISFACTION LEVELS

\begin{tabular}{|l|c|c|c|c|c|}
\hline & N & Min & Max & X & Sd \\
\hline Students' satisfaction & 200 & 30 & 200 & 63.53 & 24.2 \\
\hline
\end{tabular}

\section{2) Question 2}

As shown in Table III, there was no significant difference between male or female students' degree of satisfaction in which, $t(70)=1.78$ and $p=0.079>0.05$. Therefore, it can be said that there was no considerable relationship between students' satisfaction degree and gender which is supported by other investigations in the literature $[21,22]$.

TABLE III. STUDENTS' SATISFACTION LEVEL BASED ON GENDER

\begin{tabular}{|c|c|c|c|c|c|c|}
\hline Gender & N & X & SS & Sd & t & P \\
\hline Female & 59 & 43 & 28.4 & 70 & 1.78 & 0.079 \\
\hline Male & 141 & 58.5 & 23.9 & & & \\
3) Question 3
\end{tabular}

A one-way ANOVA was applied to examine the statistical relationship among the students' different age groups and their satisfaction level of using LMS. Table IV provides the descriptive statistics of satisfaction level based on age and the results are shown in Table V.

TABLE IV. DESCRIPTIVE STATISTICS OF SATISFACTION LEVEL BASED ON AGE

\begin{tabular}{|c|c|c|c|}
\hline Age & N & X & Std. Deviation \\
\hline $\mathbf{2 0 - 3 0}$ & 182 & 62.5055 & 24.37727 \\
\hline $\mathbf{3 1 - 4 0}$ & 7 & 64.4286 & 27.21432 \\
\hline $\mathbf{4 1}+$ & 11 & 79.8182 & 11.90645 \\
\hline Total & 200 & 63.5250 & 24.19933 \\
\hline
\end{tabular}

TABLE V. STUDENTS' SATISFACTION LEVEL BASED ON AGE

\begin{tabular}{|c|c|c|c|c|c|}
\hline $\begin{array}{c}\text { Variance } \\
\text { Source }\end{array}$ & Sum of Squares & Sd & Mean Square & F & p. \\
\hline $\begin{array}{c}\text { Between } \\
\text { Groups }\end{array}$ & 3115.030 & 2 & 1557.515 & & \\
\hline Within Groups & 113420.845 & 197 & 575.740 & 2.705 & 0.069 \\
\hline Total & 116535.875 & 199 & & & \\
\hline
\end{tabular}

As shown, age has no significant impact on students' level of satisfaction $[\mathrm{F}(2.197)=2.71, \mathrm{p}=0.69>0.05]$. These findings are consistent with [22-24]. However, it has been stated that older respondents are generally more satisfied with LMSs [21].

\section{4) Question 4}

A one-way ANOVA was conducted to test students' satisfaction level based on their grades. Descriptive statistics of satisfaction level associated with age groups is given in Table VI and the results are shown in Table VII.

TABLE VI. DESCRIPTIVE STATISTICS OF SATISFACTION LEVEL BASED ON GRADE

\begin{tabular}{|c|c|c|c|}
\hline Grade & $\mathbf{N}$ & $\mathbf{X}$ & Std. Deviation \\
\hline $\mathbf{1}$ & 9 & 43.0000 & 28.39454 \\
\hline $\mathbf{2}$ & 63 & 58.5079 & 23.87256 \\
\hline $\mathbf{3}$ & 63 & 64.0952 & 21.63533 \\
\hline $\mathbf{4}$ & 39 & 74.3846 & 23.57141 \\
\hline Master and PhD & 26 & 65.1154 & 24.12853 \\
\hline Total & 200 & 63.5250 & 24.19933 \\
\hline
\end{tabular}

TABLE VII. STUDENTS' SATISFACTION LEVEL BASED ON GRADE

\begin{tabular}{|c|c|c|c|c|c|c|}
\hline $\begin{array}{c}\text { Variance } \\
\text { Source }\end{array}$ & $\begin{array}{c}\text { Sum of } \\
\text { Squares }\end{array}$ & Sd & $\begin{array}{c}\text { Mean } \\
\text { Square }\end{array}$ & F & P & $\begin{array}{c}\text { Significant } \\
\text { Difference }\end{array}$ \\
\hline $\begin{array}{c}\text { Between } \\
\text { Groups }\end{array}$ & 10062.816 & 4 & 2515.704 & 4.607 & 0.001 & $3 / 1$ \\
\hline $\begin{array}{c}\text { Within } \\
\text { Groups }\end{array}$ & 106473.059 & 195 & 546.016 & & & $4 / 1$ \\
\hline Total & 116535.875 & 199 & & & & $\begin{array}{c}\text { Master and } \mathrm{PhD} \\
/ 1\end{array}$ \\
\hline
\end{tabular}

As shown, students' grades play a significant role on their satisfaction level $(p<0.05)$ [F $(4.195)=4.61, p=0.001]$. Post hoc comparisons with the LSD test specified that the mean score for the 3rd grade students group $(X=64.09, S D=21.64)$ was dramatically different from the 1 st grade students group $(X=43.00, S D=28.39)$. Moreover, the mean score for the 4th grade students group $(X=74.38, S D=23.57)$ was significantly different from that of the 1 st grade students group $(X=43.00$, $\mathrm{SD}=28.39)$. In addition, there was a considerable difference between the Master and $\mathrm{PhD}$ group $(\mathrm{X}=65.12, \mathrm{SD}=24.13)$ and the 1st grade students group $(X=43.00, S D=28.39)$. Generally, it can be concluded that the higher the grade, the more the satisfaction level in using the LMS. As it can be seen, master and $\mathrm{PhD}$ groups as well as 4th grade student group had the highest satisfaction level in using LMSs. These findings are also supported by [24-25].

\section{5) Question 5}

The study in a one-way ANOVA test was applied to examine the statistical relationship between different faculty 
groups and satisfaction level of using LMS. Descriptive statistics are shown in Table VIII and results in Table IX.

TABLE VIII. DESCRIPTIVE STATISTICS OF SATISFACTION LEVEL BASED ON DEPARTMENT

\begin{tabular}{|c|c|c|c|}
\hline Department & $\mathbf{N}$ & $\mathbf{X}$ & Std. Deviation \\
\hline Science & 76 & 64.6316 & 23.89301 \\
\hline Engineering & 123 & 62.7724 & 24.54264 \\
\hline Total & 200 & 63.5250 & 24.19933 \\
\hline
\end{tabular}

TABLE IX. STUDENTS' SATISFACTION LEVEL BASED ON DEPARTMENT

\begin{tabular}{|c|c|c|c|c|c|}
\hline $\begin{array}{c}\text { Variance } \\
\text { Source }\end{array}$ & Sum of Squares & Sd & $\begin{array}{c}\text { Mean } \\
\text { Square }\end{array}$ & F & P \\
\hline $\begin{array}{c}\text { Between } \\
\text { Groups }\end{array}$ & 234.565 & 2 & 117.282 & & \\
\hline Within Groups & 116301.310 & 197 & 590.362 & 0.199 & 0.820 \\
\hline Total & 116535.875 & 199 & & & \\
\hline
\end{tabular}

As shown, the department has no significant impact on students' satisfaction level [F (2.197) $=0.199, \mathrm{p}=0.82>0.05$ ] which is consistent with $[25,26]$.

6) Questions 6-10:

In this part, LMS satisfaction dimensions including PU, PEU, BIT, ATUT, and ATU were examined. As it can be seen in Table X, PU had 6 items $(\min =6, \max =24)$, PEU had 5 items $(\min =5, \max =20)$, BIT 4 items $(\min =4, \max =16)$, ATUT had 8 items $(\min =8, \max =32)$, and ATU had 7 items $(\min =7$, $\max =28$ ), respectively.

TABLE $\mathrm{X}$. SATISFACTION DIMENSIONS' SCORES

\begin{tabular}{|c|c|c|c|c|}
\hline Dimensions & $\mathbf{N}$ & $\mathbf{X}$ & $\mathbf{\%}$ & $\begin{array}{c}\text { Std. } \\
\text { Deviation }\end{array}$ \\
\hline Perceived Usefulness & 200 & 12.74 & 53.08 & 6.15 \\
\hline Perceived Ease of Use & 200 & 10.22 & 51.1 & 5.05 \\
\hline $\begin{array}{c}\text { Behavioral Intention to Use } \\
\text { Technology }\end{array}$ & 200 & 9.04 & 56.5 & 4.26 \\
\hline $\begin{array}{c}\text { Attitude Toward Using } \\
\text { Technology }\end{array}$ & 200 & 17.63 & 55.09 & 8.08 \\
\hline Actual Technology Use & 200 & 13.90 & 49.64 & 6.50 \\
\hline
\end{tabular}

According to Table $\mathrm{X}$, most of the students were satisfied with the LMS dimensions. The students' satisfaction level is $12.74(53 \%)$ at LMS perceived usefulness. Similar results can be seen in the research in [36]. In [37] it was indicated that in order to reach effective and efficient results on LMSs, PU should be precisely examined. The students' satisfaction level is $10.22(51.1 \%)$ at LMS dimension perceived ease of use. Similar results can be seen in [36]. Therefore, it can be said that LMSs actually influenced students' progress [37]. The students' satisfaction level at behavioral intention to use the technology of LMSs is 9.04 (56.5\%). Similarly, in [32], it was mentioned that students' intention to use technology has a positive effect on user satisfaction. In [38], it was that BIT had a significant effect on the students' satisfaction. The students' satisfaction level is $17.63(55 \%)$ at attitude toward using technology of LMS in accordance with $[39,40]$. The students' satisfaction level at actual technology use of LMSs is 13.90 $(49.64 \%)$, in accordance to $[41,42]$.

\section{DisCUSSION AND CONCLUSION}

Payamnoor and Farhangian LMSs attempt to provide a user-friendly environment for learners with the aim of evolution in e-learning. These two LMS providers have a remarkable capacity for development and innovation. For this purpose, it is crucial to have a better understanding of Iranian students' needs, requirements, and expectations to optimize the LMS. In general, the quality and the current mechanism of Payamnoor and Farhangian LMSs is not perfect, but it can be improved gradually by continuous study and data analysis. Considering the survey reports, Payamnoor and Farhangian LMSs usage, for the vast majority of Iranian students regardless their gender, age, and department was satisfactory. However, there were some discontent regarding the platform and systematic design of both LMS. Learners' grade was documented as the crucial factor in satisfaction level.

\section{REFERENCES}

[1] K. Gilhooly, "Making e-learning effective", Computerworld, Vol. 35, No. 29, pp. 52-53, 2001

[2] M. Szabo, K. Flesher, CMI Theory and Practice: Historical Roots of Learning Management Systems, 2002

[3] M. Milošević, E. Zećirović, R. Krneta, "Technology acceptance models and learning management systems: case study", Fifth International Conference on e-Learning (eLearning-2014), Belgrade, Serbia, September 22-23, 2014

[4] C. M. Stracke, "Open learning: The concept for modernizing school education and lifelong learning through the combination of learning innovations and quality" in Learning Innovations and Quality: The Future of Digital Resources, Rome, 2013

[5] J. Caballero, M. Palomo, J. M., Dodero, G. Rodríguez, M. S. Ibarra, "Integrating external evidences of skill assessment in virtual learning environments", Fifth International Conference on e-Learning, Belgrade, Serbia, 2014

[6] W. R. Watson, S. L. Watson, "An argument for clarity: what are learning management systems, what are they not, and what should they become?", TechTrend, Vol. 51, No. 2, pp. 28-34, 2007

[7] S. D. Lonn, Student use of a learning management system for group projects: a case study, Investigating Interaction, Collaboration, and Knowledge Construction, PhD Thesis, University of Michigan, 2009

[8] PNUNews, from http://www.pnuna.com, 2014

[9] S. Tinschert, Implementation of a Learning Management System for a small American company, $\mathrm{PhD}$ Thesis, University of Applied Sciences, 2006

[10] Brandon-Hall, "Learning management and knowledge management: Is the holy grail of integration close at hand?", Brandon-Hall White Paper, available at: http://www.providersedge.com/docs/km_articles/Learning Management_and_KM_Integration.pdf

[11] D. A. Falvo, B. F. Johnson, "The use of learning management systems in the United States", TechTrends, Vol. 51, No. 2, pp. 40-45, 2007

[12] S. Iqbal, I. A. Qureshi, "Learning management systems (LMS): inside matters", Information Management \& Business Review, Vol. 3, No. 4, pp. 205-206, 2011

[13] D. Davis, "Perceived usefulness, perceived ease of use, and user acceptance of information technology", MIS Quarterly, Vol. 13, No. 3, pp. 319-340, 1989

[14] M. Fishbein, I. Ajzen, Belief, attitude, intention, and behavior: an introduction to theory and research. Reading, MA: Addison - Wesley, 1975

[15] V. Venkatesh, F. Davis, "A theoretical extension of the technology acceptance model: four longitudinal field studies", Management Science, Vol. 46, No. 2, pp.186-204, 2000 
[16] H. M. Jogiyanto, Model Kesuksesan Sistem Teknologi Informasi, Andi Offset, Yogyakarta 55281, 2007

[17] J. Siang, H. B. Santoso, "Students' perspective of learning management system: an empirical evidence of technology acceptance model in emerging countries", Researchers World, Vol. 4, No. 2, pp. 1-14, 2015

[18] Z. Suradi, N. S. Abdulrani, "Assessment on contents of the learning management system", International Journal of Scientific \& Engineering Research, Vol. 4, No. 5, pp. 2229- 5518, 2013

[19] S. K. Min, F. M. Yamin, W. H. W. Ishak, "Design, purpose of usage and the impact of LMS on student learning: a preliminary finding". Knowledge Management International Conference (KMICe), Johor Bahru, Malaysia, 2012

[20] G. Naveh, D. Tubin, N. Pliskin, "Student satisfaction with learning management systems: a lens of critical success factors", Technology, Pedagogy and Education, Vol. 21, No. 3, pp. 337-350, 2012

[21] C. Chua, J. Montalbo, “Assessing students' satisfaction on the use of virtual learning environment (VLE): an input to a campus-wide elearning design and implementation", Information and Knowledge Management, Vol. 3, No. 4, pp. 108-115, 2014

[22] M. Marmon, J. Vanscoder, J. Gordesky, "Online student satisfaction: an examination of preference, asynchronous course elements and collaboration among online students", Current Issues in Education, Vol. 17, No. 3, pp. 1-11, 2014

[23] R. A. Tajuddin, M. Baharudin, T. S. Hoon, "System quality and its influence on students' learning satisfaction in uitm shah alam", Procedia-Social and Behavioral Sciences, Vol. 90, No. 3, pp. 677-685, 2013

[24] O. Cakir, "The factors that affect online learners' satisfaction", Anthropologist, Vol. 17, No. 3, pp. 895-902, 2014

[25] E. Dahlstorm, D. C. Brooks, J. Bichsel, The current ecosystem of learning management systems in higher education: student, faculty, and it perspectives, Research report EDUCAUSE, 2014

[26] B. Rubin, R. Fernandes, M. D. Avgerinou, J. Moore, "The effect of learning management systems on student and faculty outcomes", The Internet and Higher Education, Vol. 13, No. 1, pp. 82-83, 2010

[27] H. Shen, L. Luo, Z. Sun, “What affect lower grade learner's perceived usefulness and perceived ease of use of mobile digital textbook learning system? An empirical factor analyses investigation in China", International Journal of Multimedia and Ubiquitous Engineering, Vol. 10, No. 1, pp. 33-46, 2015

[28] A. Raman, "The usage of technology among education students in university Uttara Malaysia: an application of extended technology acceptance model", International Journal of Education and Development using Information and Communication Technology, Vol. 7, No. 3, pp. 4-17, 2011
[29] C. Claar, L. P. Dias, R. Shields, "Student acceptance of learning management systems: a study on demographics", Issues in Information Systems, Vol. 15, No. 1, pp. 409-417, 2014

[30] S. Alharbi, S. Drew, "Using the technology acceptance model in understanding academics' behavioral intention to use learning management systems", International Journal of Advanced Computer Science and Applications, Vol. 5, No. 1, pp. 143-155, 2014

[31] E. Kurkinen, "The effect of age on technology acceptance among field police officers", 10th International ISCRAM Conference, Baden, Germany, Kurkinen, 2013

[32] S. Y. Park, "An analysis of the technology acceptance model in understanding university students' behavioral intention to use elearning", Educational Technology \& Society, Vol. 12, No. 3, pp. 150162,2009

[33] J. P. McCombs, A path analysis of the behavioral intention of secondary teachers to integrate technology in private schools in Florida, UNF Digital Commons, University of North Florida, USA, 2011

[34] C. P. Lim, Y. Zhao, J. Tondeur, C. S. Chai, C. C. Tsai, "Bridging the gap: technology trends and use of technology in schools", Educational Technology \& Society, Vol. 16, No. 2, pp. 59-68, 2013

[35] U. Sekaran, Research methods for business: A skill building approach, John Wiley \& Sons, 2006

[36] N. A. K. M. Islam, "Understanding e-learning system usage outcomes in hybrid courses", IEEE 45th Hawaii International Conference on System Sciences, University of Turku, Finland, 2012

[37] N. Kripanont, Examining a technology acceptance model of internet usage by academics within the business schools, Victoria University Melbourne, Australia, 2007

[38] W. C. Tsai, "A study of consumer behavioral intention to use e-books: the technology acceptance model perspective", Innovative Marketing, Vol. 8, No. 4, pp. 55-66, 2012

[39] M. Metin, G. K. Yilmaz, K. Coskun, S. Birisci, “ Developing an attitude scale towards using instructional technologies for pre-service teachers", The Turkish Online Journal of Educational Technology, Vol. 11, No. 1, pp. 36-45, 2012

[40] N. J. Al-Zaidiyeen, L. L. Mei, F. S. Fook, “Teachers' attitudes and levels of technology use in classrooms: the case of Jordan schools", International Education Studies, Vol. 3, No. 2, pp. 211- 218, 2010

[41] T. R. Liyanagunawardena, "Measuring student perception and actual usage of online learning management system", Communications of the IBIMA, Vol. 4, No. 21, pp. 165-168, 2008

[42] S. Psycharis, G. Chalatzoglidis, M. Kalogiannakis, "Students' acceptance of a learning management system for teaching sciences in secondary education", 2011, available at: https://tinyurl.com/ycv3jmkk 